\title{
Determinants of Enterprise Performance in Uganda's Tourism Sector: Does Gender Matter?
}

\author{
John Mutenyo ${ }^{1}$, Margaret Banga ${ }^{2}$, John Bbale Mayanja ${ }^{1}$, Rose $\mathrm{Nakimu}^{3}$, Ruth Nsibirano ${ }^{4}$, Dorothy Massa ${ }^{5} \&$ \\ Lawrence Kalyowa ${ }^{5}$ \\ ${ }^{1}$ Senior Lecturer School of Economics, College of Business and Management Sciences, Makerere University, \\ Uganda \\ ${ }^{2}$ Senior Lecturer School of Statistics, College of Business and Management Sciences, Makerere University, \\ Uganda \\ ${ }^{3}$ Lecturer School of Economics, College of Business and Management Sciences, Makerere University, Uganda \\ ${ }^{4}$ Senior Lecturer School of Gender and Women Studies, College of Humanities and Social Sciences, Makerere \\ University, Uganda \\ ${ }^{5}$ Freelance Researchers, Uganda \\ Correspondence: John Mutenyo, The author is a Senior Lecturer of Economics in the College of Business and \\ Management Sciences, Makerere University, Kampala Uganda. E-mail: jkmutenyo@yahoo.com
}

Received: June 20, 2021

doi:10.5539/ijbm.v16n10p63
Accepted: August 5, 2021

Online Published: August 25, 2021

\begin{abstract}
The paper looks at the relationship between the performance of small and medium-sized enterprises (SMEs) in the tourism sector of Uganda and firm characteristics and business environment. Data were gathered after administering questionnaires to 1690 SMEs located around tourist attractions throughout the country in 2018 . The study uses quantile regression to analyze the determinants of firm performance. The findings indicate that entrepreneur/managers education, business experience, initial capital, business registration and age of the owner are important in explaining enterprise performance. We also find that male managed enterprises outperform those managed by female. The study suggests that providing easy access to credit for initial capital and easing the business registration process and training entrepreneurs/managers will increase performance of SMEs in the tourism industry.
\end{abstract}

Keywords: enterprise performance, tourism sector, gender and Uganda

JEL Classification: L26, Z3, Z32.

\section{Introduction}

In many developing countries, the contribution of Small and Medium Enterprises (SMEs) includes employment creation, increased output, promotion of exports, fostering entrepreneurship and ultimately higher economic growth. Entrepreneurship plays a key role in the tourism sector due to its social, economic and environment impacts. Socially, the benefits are enjoyed by peasants, artisans and even professionals regardless of age and gender. At the environmental level, tourism conserves nature, preserves antiquities, historical monuments and culture. Economically, tourism creates employment especially to the youth and women and a source of foreign exchange to a country. (Ndanusa et al., 2014).

In addition, SMEs play a big part in furthering innovation and prosperity (McIntyre, 2000) and also for making new products and services available to consumers and contributing significantly to Gross Domestic Product (GDP). Furthermore, the SME sector is one of the sources of hope in bringing transformation to stunted growth, a move which will improve overall living standards of the population. The positive relationship between entrepreneurial development and economic growth has been recognized in both developed and less developed countries (Gobson, 2006; Monk, 2000). It is therefore critical that the entrepreneurial firm's dynamics are well understood to better guide entrepreneurial decisions and policy formation in the areas that are economically underdeveloped or depressed. 


\subsection{Uganda's Tourism Sector and Entrepreneurship}

Tourism is one of Uganda's fastest growing industries and makes an important contribution to the development of the country. Tourism industry is the single largest export earner and generator of foreign exchange. In 2016, it accounted for over 23.5 percent of total export, despite the limited share of the national budget; the sector has over the years received about 0.1 percent of the national budget (GOU, 2016; 2017 and 2018). However, its contribution to the country's GDP rose from US\$ 1.8 billion (6.6 percentage share) in 2016 to USD 1.9 billion (7.3 percentage share) in 2017, and this is expected to increase to 10.2 percent in 2025, (Travel \& Tourism Economic Impact Report 2017, 2018 Uganda). The tourism industry is envisaged to absorb many unemployed individuals and contribute to poverty reduction and transformation of the Ugandan society from a peasant to a modern and prosperous country by 2040. This is because most of the enterprises in the tourism industry do not need a lot of capital to start and run. In addition, since the tourism industry is labor intensive, it provides job opportunities to both skilled and unskilled, making it attractive to a large proportion of the unemployed and underemployed population most of whom are women and youths. Female employment is believed to be higher in the tourism sector relative to other sectors though these jobs are concentrated in sections that require low skills hence fetch low incomes for instance cooking, cleaning and hospitality (Global Report on Women in Tourism, 2011).

Over the last several years, the government of Uganda has undertaken steps to promote growth of the entrepreneurial businesses. The most recent reforms include reductions in business tax rates. While these reforms are encouraging, there is much more that needs to be done because the costs of doing business has remained high, also there are high financial barriers, poor infrastructure, and lack of competitive market structure, which discourage creation and growth of small enterprises. Small businesses find it difficult to compete against large, well established nation-wide franchises. However, Uganda's tourism sector is not employing as many people as its potential could have been because of the constraints many enterprises face in the tourism sector. Although in 2015, Uganda was ranked as the most entrepreneurial country (Global Entrepreneurship Monitor -GEM, 2016), the enterprises set up in Uganda have a high under five mortality rate. Even those that persevere beyond five years do not expand beyond certain limits (that is, most of them fail to graduate upwards from one level to another).

Given the important role played by SMEs in Uganda, in addition to understanding their challenges, there is need to pay attention to the demographic and socio-economic factors that impact on the performance of small businesses, particularly those that operate in the tourism sector of Uganda. Accordingly, the question which needs to be answered relates to the factors that are critical for the enterprise performance in Uganda's tourism sector and whether gender matters.

This study therefore aims at unfolding some of the drivers of performance in the tourism sector with the hope of arming policy makers with practical and supportive tourism policies. This will be important not only for improving operations and service delivery for the SMEs but also highlighting key entry points in terms of policy intervention. The study examined the effects of the characteristic of the owner and the enterprise, and business environment on performance of the enterprises.

\subsection{Significance of the Study}

Albeit the above, there is no clear evidence on the factors responsible for the performance of enterprises in the tourism industry in Uganda. Studies related to this issue, have concentrated on particular regions in their respective countries (Nieman, et. al., 2008 in Gauteng and Mpumalanga regions- South Africa; Mpele, 2016 in KwaZuluNatal region-South Africa; Mugure, 2017 in Nairobi region, Kenya; Baporikar et. al, 2016 in Khomas regionNamibia). In addition, other studies have concentrated on Enterprises in the other sectors of the economy, not necessarily the tourism sector (Soini and Veseli, 2011 in Kosovo covering agriculture and construction sectors). Other studies have concentrated on female entrepreneurial businesses in the tourism sector, (Tundui, 2011 in Tanzania; Msoka, 2013 in Tanzania; Zapalska and Brozik, 2014 in Poland). In this study, we examine the determinants of performance of enterprises in Uganda's tourism sector, using primary data collected from enterprise owners/managers from all regions of the country.

\section{Brief Literature Review}

\subsection{Theoretical Reviews}

This section is instrumental in identifying the factors affecting enterprise performance in the general term and tourism sector in particular. It provides a justification for selection of some of the variables which were used in the analysis to explain performance.

Previous studies have shown that factors that determine performance of SMEs can be grouped into entrepreneur characteristics (Kristiansen, Furuholt, \& Wahid, 2003), firm characteristics, management and financial resources 
(Swierczek \& Ha, 2003), and external environment (Indarti \& Langenberg, 2005). But Duh (2003) explored owners' or managers' attributes and firm characteristics as the major determinants of SMEs performance.

Some authors such as Lussier (1995) claim that there is no generally accepted list of factors that can explain firm performance. Many arguments put forward to explain firm performance lie in the structure, conduct, and performance (SCP) framework (Rosli, 2011). According to the SCP framework, performance is determined by the conduct and structure of the market (Ferguson, 1993). Rodgers (2000) asserts that, within the SCP tradition, profitability is positively related to higher levels of industry concentration and firm's market share. It is therefore clear that with the SCP framework, it is the behavior of firms in the market (conduct) and the environment in which firms operate (structure) that matters to performance. Under strategic management, key factors believed to influence firm performance are; ownership structure, marketing and other firm specific factors (McGahan and Porter, 1997; Brooksbank et al., 1992 and Kotler, 1988) This sounds more relevant to the tourism sector, and therefore to this study, since enterprises in this sector need specialized skills to meet growing consumers' demand and to outperform competitors.

Various studies have provided several factors that influence firm performance, among these includes: firm size and age, initial amount of capital, foreign share capital, level of competition. Others are gender, age and level of education of the entrepreneur and firm ownership (Wengel \& Rodriguez 2006; Sarder et al, 1997; Remi et al., 2010; Wynarczyk \& Watson 2005).

\subsection{Empirical Reviews}

Several factor both firm and entrepreneur specific have been found to influence performance of enterprises. For instance Pena (2002) and Bosma et al. (2004) stress that higher financial capital is a key factor in the performance of an enterprise. These findings are closely related to those of Schiffer and Weber (2001) who measured firm size using number of employees and found that smaller firms perform worse than larger firms. But company age and firm performance have been found to be negatively related (Begley and Boyd 1985, Dunne and Hughes, 1994). This finding is supported by Stuart and Arbetti (1990) who found that age of the CEO proxying for an experience indicator does not affect performance. This could be due to findings by O'Gorman (2001) who states that over time, personality and lack of managerial skills could be hindrance to enterprise growth. To overcome this, Bosma et al. (2004) finds that firm performance can be enhanced by higher level of education of the manager. This is supported by Charney and Libecap (2000) who found that training in entrepreneurship enhances enterprise performance. Similarly, Sinha (1996) find that entrepreneurs with technical education performed better than their counterparts who did not have any technical education.

Further, at the entrepreneurial level, Chandler (1996) finds that expertise and behavior of the founder strongly influences the performance of an enterprise. In a related study, Roper (1999) finds a positive effect of the ownermanagers' experience on profitability but no effect on growth. And using a composite measure of previous managerial experience and industrial experience, Dyke et al. (1992) finds a positive relationship with firm performance. In a related studies, McMahon (2001) and Kristiansen, et al., (2003) found that experience enterprise's owner or manager significantly effects business performance of SMEs. Similarly, Fairoz et al. (2010) find a positive and significant relationship between entrepreneurial pro-activeness and SMEs performance. In a study on Malaysian small and medium enterprises, Adnan, et al., (2011) find a significant and positive relationship between human resources management practices and firm performance.

However, Reuber and Fisher, (1999) state that due to the learning curve, experience and firm performance may not be linearly related. Instead, at the beginning of one's tenure, there is much willingness to change, but this gradually fades. Hence the literature is not clear whether manager/CEO experience affects firm performance. In some cases it is positive, while in some it is not significant.

Regarding enterprise characteristics, McMahon (2001) showed that enterprise size had a significant and positive effect on performance of SMEs. Tundui (2012) examines survival and performance of SMEs in Tanzania and focuses on gender of enterprise owner. Using stratified sampling procedure and logistic regression, he shows that financial capital has a positive impact on male business growth aspiration while access to loan positively impacts on business growth aspiration for women. He also showed that family labour has a negative impact on enterprise growth. In a related study, Grazzi et al., (2016) investigate firm level sources of productivity growth. They measure firm performance using firm level productivity. Using World Bank Enterprise Survey of 2010, they document that factors which affect productivity are Innovation, ICT usage, on-job training, firm age, firm size, access to credit and international linkages. The study further found a 10:1 difference in labor productivity among manufacturing firms in the $90^{\text {th }}$ and $10^{\text {th }}$ percentiles.

Studies have also showed that external environmental factors are important for performance of businesses. For 
instance, Keh et al. (2007) found a positive and significant relationship between information utilization and performance of small and medium enterprises. In a related study, Cacciolatti, et al., (2011) found that use of welldesigned marketing strategies, positively impact performance of small and medium enterprises. Similarly, in a study on performance of SMEs in Ghana, Mahmoud (2011) found that higher level of market orientation had a positive impact on enterprise performance. Soini and Veseli (2011) qualitatively examines the external and internal factors that affect growth of SMEs in Kosovo. Their findings revealed that the major factors of firm growth were lack of access to finance, competition, corruption, globalization, laws and regulations, management competence, lack of skilled labor, and low investment in innovation, technology and marketing. Moura et al, (2020) on the other hand, investigate the influence of absorptive capacity, cooperation and government financial support for innovation on innovative performance of Portuguese enterprises. Using logistic regression, the study finds that internal cooperation significantly influence innovative performance of enterprises.

Zena (2013) studies the constraints to growth of SMEs in Zanzibar with a principal aim of determining the dominant constraints from the five constraints (lack of entrepreneur skill, unfavorable government regulations, lack of access to finance and power supply, and unreliable water supply). The study looks at 70 small firms in fields of services, food processing, agriculture and tourism and he uses a logistic regression model estimation. The study findings show that unfavorable government regulations and unreliable power supply significantly hinder SME growth in Zanzibar. Waseem et al., (2020) investigated the role of capital mix on the success of women owned micro-enterprises in Pakistan. They found that financial capital, social capital and human capital have a positive and significant effect on the success of women owned micro-enterprises.

Nganda et al. (2014) looked at factors which influence growth of SME in Kakamega, Central sub-County, Kenya, using 103 registered SMEs and they found out that higher taxes hinder SMEs growth. Relatedly, Baporikar, (2016) explore the factors hindering SMEs' growth in Namibia using qualitative approach, The study revealed that, theft, lack of access to finance, and skilled manpower, poor marketing strategies, and customer service are the main factors that impede enterprise growth.

Using face to face interview method on 150 owners/managers, Mpele (2016) examines the determinants of the survival and growth of SMEs in rural KwaZulu - Natal Province. Results indicate that the major constraints to businesses growth were, size of the market, poor infrastructure, inadequate finance, and tough government regulations, unfavorably impacted on SME growth. In a related study Mabhungu and Breggie (2017) report that performance of Micro, Small and Medium Enterprises (MSMEs) in South Africa depend mainly on entrepreneur attributes such as on owner and employee commitment, business planning and external factors such as customers and input suppliers loyalty, market information, competition and availability of capital. Relatedly, Yildiz et al. (2021) adopted a micro-foundation perspective to study how goal orientations of employees affect their individuallevel absorptive capacity. In addition, they examine conditions that influence individual's innovative performance. Their findings showed that individual's absorptive capacity is influenced by their learning and orientation. Further they found that innovative performance is determined by individual's absorptive capacity.

Probably different from the traditional factors, Kusuma et al. (2019) investigate the effect of religious values and technology adoption on performance of SMEs in Indonesia. Findings show that Islamic work ethics has no direct effect on SME's performance, but technology adoption positively and significantly affect SME's performance.

The above literature shows that different factors affect enterprise development differently across countries and regions. This means that we cannot use the conclusions in the literature above for the Ugandan Case. Identifying the determinants of enterprise performance in Uganda's tourism sector will enable policy makers to design strategies to promote sustainable enterprise development in Uganda's tourism sector.

\section{Methodology}

\subsection{Measurement of Performance}

According to Rosli (2011), measurement of enterprise performance can be done in many ways. One can use either tangible or intangible measures or even both. Tangible measures are easier to measure and operationalize, those mostly used in literature are profitability, return on investment and productivity. In addition, the ability of an enterprise to generate higher sales, and employ more workers have been recognized as key measures of performance (Haber \& Reichel, 2005; Getz et al., 2005). On the other hand, the challenge with intangible measures is that they are not easy to measure and in most cases defining intangible measures can be inaccurate because of subjective judgment. Intangible measures of performance include: trust (Saad \& Patel, 2006), stakeholder satisfaction (Garrigos-Simon et al., 2005), and quality of product (Abu Kasim et al., 1989). This study used tangible measures of firm performance, specifically average monthly sales due to the aforementioned advantages. 


\subsection{Model and Variables}

The study used log of average monthly sales as the dependent variable because there was a wide range in the average sales of the enterprises. Transforming data into log, stabilizes the variable. The model is specified in equation 1.

$$
\operatorname{LogFirmPerf}_{i j}=\alpha+\beta \text { Enterp }_{i j}+\delta B u \operatorname{sen} v_{j}+\varepsilon_{i j}
$$

Where FirmPerfij denotes SMEs sales performance, Enterp $p_{i j}$ is a vector of entrepreneur's characteristics and Busenv $v_{j}$ is a vector of business environment.

Explanatory variables examined under entrepreneur's characteristics include: age of owner/manager, experience of owner/manager, education of owner and gender. Entrepreneurial characteristics include firm age, initial capital, price determination, type of enterprise, family business history, business training while business environment included business registration, access to credit, competition, location of enterprises and others.

Table1 summarizes the expected relationship between enterprise performance and some explanatory variables as documented in the literature.

Table 1. Measurement of variables and the expected signs

\begin{tabular}{lll}
\hline Variable & Measurement & Expected sign \\
\hline Sales & The average monthly sales was used as the performance measure. & + or - \\
Age of the firm owner/manager & Age in complete years of the enterprise owner/manager & + \\
Age of firm & Number of years of the enterprise & + \\
Education & Level of education of enterprise owner/manager & - \\
& 0 - no education, 1. Primary 2. Secondary 3. Tertiary & + \\
Gender of owner & Sex of enterprise owner 1=Female, $0=$ Male & + \\
Price determination & Method of determining prices 1= bargaining with customers and $0=$ otherwise & + \\
Family business history & At least one member of the family was doing the same business $=1,0=$ otherwise & + \\
Type of business & $1=$ Accommodation 2. hotel and bar 3. Tourism services 4. Others & + \\
Lack of Competition & $1=$ there are no competitors \\
& $0=$ otherwise \\
Foreign share in capital structure & $1=$ has foreign shares \\
& $0=$ Purely local \\
\hline
\end{tabular}

\subsection{Data Sources and Analysis}

Cross-sectional firm-level data from 1690 enterprises that operate near tourist sites in Uganda were collected, out of which, data from 1629 enterprises were usable. The criteria for the selection focused on small enterprises with no more than 50 workers in the tourism sector. The survey was conducted in November and December 2018. The data were collected by in-person interviews. The sub-sectors covered included: hotel and accommodation, restaurants, crafts, transportation, tours and travel, and other tourism services.

To understand the determinants of enterprise performance, equation 1 was estimated using Quantile Regression. Quantile Regression helps to determine the effect of the independent variables on the dependent one over each quantile of the dependent variable. Regression using the Ordinary Least Squares (OLS) method only obtains a single regression line that represents the conditional average value of the dependent variable $\mathrm{Y}$ by the values of the independent variable $\mathrm{X}$. In the meantime, quantile regression shows multiple regression functions corresponding to each quantile of dependent variable.

Table 2 shows the summary statistics of some of the variables used in the performance model.

From the table, we see that the monthly average sales amount to UGX10,800,000, and average initial capital is UGX19,700,000. Forty-one percent of the enterprise owners/managers were females, and the average age for the entrepreneurs was 32 years. The average number of years the enterprises have been in existence is 9 years and 81 percent of the enterprises are registered. We observe that the decision to start the business was initiated by majority of the entrepreneurs themselves ( 72.2 percent). Further, 44 percent of the firms have employees and 90.3 percent of the enterprises have competitors. 
Table 2. Summary statistics of selected variables

\begin{tabular}{llll}
\hline Variable & Number of observations & \multicolumn{1}{c}{ Mean } & Std. Dev. \\
\hline Monthly sales & 1512 & $10,800,000$ & $3,960,000$ \\
Sex & 1620 & 0.4099 & \\
Age & 1613 & 32.36206 & 9.779979 \\
Initial capital & 1208 & $19,700,000$ & $27,900,000$ \\
Firm age & 1581 & 8.930424 & 8.597628 \\
Employees & 1629 & 0.4413751 & 0.496704 \\
Who initiated business idea & 1629 & 0.7249847 & 0.446659 \\
Registration status & 1609 & 0.8085768 & 0.393544 \\
Competition & 1594 & 0.9228356 & 0.266936 \\
Family business & 1629 & 0.2676489 & 0.44287 \\
Record keeping & 1629 & 0.8520565 & 0.355153 \\
Business decision & 1629 & 0.5488029 & 0.497765 \\
\hline
\end{tabular}

Table 3 presents the regression results for the determinants of enterprise performance. Our results show that business registration, initial capital, tertiary education and firm age, positively affect enterprise performance across all quantiles. These results also show that registered businesses perform better than unregistered businesses and this could be because such businesses enjoy some benefits which unregistered businesses cannot. For example registered businesses can easily access loans which can be used to boost their business. In terms of initial capital, the higher the amount of capital the enterprise started with, the higher their sales. This could be because with a high initial capital, the enterprise is able to have enough and variety of stock which can attract the tourists hence increasing their sales.

Table 3. Determinants of SME performance (sales)

\begin{tabular}{|c|c|c|c|c|c|c|}
\hline Variable & 0.25 Quantile & $\mathrm{p}$-value & 0.50 Quantile & p-value & 0.75 Quantile & p-value \\
\hline Female/owner/manager & $-0.3308 * * *$ & 0.007 & $-0.2506^{* *}$ & 0.047 & -0.1773 & 0.332 \\
\hline Business Registration & $0.4312 * * *$ & 0.002 & $0.5403 * * *$ & 0.000 & $0.4127 * *$ & 0.048 \\
\hline \multicolumn{7}{|l|}{ Education $(\mathrm{RC}=$ None $)$} \\
\hline Primary & 0.3206 & 0.618 & 0.333 & 0.349 & 0.4398 & 0.510 \\
\hline Secondary & 0.7374 & 0.251 & $0.6392 * *$ & 0.033 & 0.7881 & 0.198 \\
\hline Tertiary & $1.0128 *$ & 0.086 & $1.021 * * *$ & 0.001 & $1.3871 * *$ & 0.034 \\
\hline Log of age & $0.4526^{* *}$ & 0.019 & $0.3907 *$ & 0.064 & 0.1463 & 0.507 \\
\hline Log of firm age & $0.1526^{* * *}$ & 0.006 & $0.1945 * * *$ & 0.000 & $0.3344 * * *$ & 0.000 \\
\hline Log of capital & $0.2914 * * *$ & 0.000 & $0.3201 * * *$ & 0.000 & $0.3310 * * *$ & 0.000 \\
\hline Source of capital -Own saving & -0.02318 & 0.879 & 0.0343 & 0.781 & -0.0097 & 0.950 \\
\hline \multicolumn{7}{|l|}{ Type of business ( $\mathrm{RC}=$ Accommodation) } \\
\hline Restaurant & 0.3613 & 0.126 & $0.3539 * *$ & 0.022 & $0.3024 * *$ & 0.019 \\
\hline Transportation & 0.3038 & 0.285 & .2663 & 0.243 & $0.4049 * *$ & 0.024 \\
\hline Tourism services & -0.07237 & 0.592 & -.2136 & 0.124 & -0.2427 & 0.261 \\
\hline Others & -0.3596 & 0.283 & $0.7011^{*}$ & 0.083 & -0.5450 & 0.545 \\
\hline Price determination-bargaining & 0091 & 0.957 & .0309 & 0.819 & -0.0592 & 0.695 \\
\hline Export (no) & -0.0695 & 0.699 & -0.0790 & 0.688 & $-0.3871 *$ & 0.099 \\
\hline Firm doesn't seek customer feed back & $-0.2647 *$ & 0.062 & -0.0940 & 0.371 & -0.1270 & 0.428 \\
\hline Business is not main source of family income & $0.2857 * * *$ & 0.004 & $0.2263^{*}$ & 0.063 & -0.0916 & 0.491 \\
\hline Family business & 0.1122 & 0.408 & 0.1151 & 0.374 & 0.0034 & 0.978 \\
\hline Specialized training & -0.1191 & 0.287 & $0.1874 *$ & 0.086 & 0.1295 & 0.392 \\
\hline Own decision to start business & 0.0531 & 0.626 & $-0.2564 *$ & 0.094 & -0.1445 & 0.259 \\
\hline Constant & 6.3109 & 0.000 & 6.7756 & 0.000 & 8.3069 & 0.000 \\
\hline observations & 972 & & 972 & & 972 & \\
\hline
\end{tabular}

It was also established that firm age and age of the owner/manager have a positive impact on performance, in other words, the longer the entrepreneur or firm stays in business, the better the performance and this could be because of learning from past mistakes and perfecting the art of doing business. Business being the main source of income 
are significant at the lower quantiles and insignificant at the highest quantile.

The results further show that female entrepreneurs perform worse than male entrepreneurs at the lower quantiles while there is no significant difference in performance between male and female entrepreneurs/managers at the high quantile. Furthermore, specialized training is only significant in the middle quantile. Enterprises with owners/managers who have received specialized training perform better than those without training. The findings demonstrate the relevance of customer feed-back to an enterprise. Firms which do not seek customer feedback perform worse in the lower quantile but customer feedback has no effect in higher quantiles. This could be because although all enterprises need customer feedback, it is needed much more in the beginning. We find that decision on price determination and whether the business is in line with other family businesses do not affect firm performance.

\section{Conclusion and Policy Implications}

Using the quantile regression, we analyzed the determinants of performance of SME in the tourism sector in Uganda. We find that initial capital, business registration, experience and gender do positively affect performance. Due to the benefits enjoyed by registered enterprises, we recommend that, all enterprises should be encouraged to become formal by easing the registration process and fees. The surveyed SMEs noted that the cost and bureaucracy in registration were some of the constraints encountered by the firms. Also there is limited start-up capital; majority of entrepreneurs start their businesses with limited capital which is mainly from their own savings. However, our results show that the higher the initial capital, the better the performance. Borrowing from Mauritius, a special bank for SMEs could be set up to enable enterprises access loans at reduced rates. In addition, the study finds that male and female entrepreneurs have equal business acumen to increase their sales performance in the higher quantile but there is a significant gap between males and females in the lower quantiles. The government has initiated special funds for women however, the management of these funds is questionable. Sometimes the targeted women for the funds do not get these funds. Special measures geared towards improving female enterprises should be considered for example monitoring and following up of the disbursed funds.

Also, we find that the enterprises with more educated owner/managers perform better than those with uneducated owners. We recommend that SMEs owners should endeavor to acquire some relevant knowledge and skills both formal and informal by attending seminars and workshops to boost their business performance. These trainings could be organized by Enterprise Uganda with help of Uganda government.

\section{Acknowledgements}

We are very grateful to the International Development Research Centre (IDRC) for their financial support towards this study. This paper is one of the research outputs from the Project, "Youth Employment and Women's Empowerment in Africa: The Role of Small and Medium Enterprises in the Tourism sector funded under Grant number 108661001.

\section{References}

Abu, K., Aziah, N., Minai, B., \& Chun, L. S. (1989). Performance measures in Malaysia - The state of the art. Malaysia Management Review, 24, 3-9.

Adnan, Z., Abdullah, H. S., \& Ahmad, J. (2011). Direct influence of human resource management practices on financial performance in Malaysian R\&D companies. World Review of Business Research, 1, 61-77.

Baporikar, N., Nambira, G., \& Gomxos, G. (2016). Exploring factors hindering SMEs' growth: Evidence from Namibia. Journal of Science and Technology Policy Management, 7(2), 190-211. https://doi.org/10.1108/JSTPM-11-2015-0036

Begley, T. M., \& Boyd, D. P. (1985). Company and chief executive officer characteristics related to financial performance in smaller business. Frontiers of Entrepreneurship Research, 452-467.

Bosma, N., Van Praag, M., Thurik, T., \& Wit, G. (2004). The Value of Human and Social Capital Investments for the Business Performance of Startups. Small Business Economics, 23, 227-236. https://doi.org/10.1023/B:SBEJ.0000032032.21192.72

Brooksbank, R., Kirby, D., \& Wright, G. (1992). Marketing and company performance: An examination of medium sized manufacturing firms in Britain. Small Business Economics, 4, 21-36. https://doi.org/10.1007/BF00389477

Cacciolatti, L., Fearne, A., \& McNeil, D. (2011) Empirical evidence for a relationship between business growth and the use of structured marketing information amongst food and drink SMEs. Academy of Marketing Conference (5-7 July 2011). University of Kent, United Kingdom. 
Chandler, G. N. (1996). Business similarity as a moderator of the relationship between pre- ownership experience and venture performance. Entrepreneurship: Theory and Practice, 20(3), 51-65. https://doi.org/10.1177/104225879602000304

Coleman, S. (2007). The role of human and financial capital in the profitability and growth of women-owned small firms. Journal of Small Business Management, 45(3), 303-319. https://doi.org/10.1111/j.1540627X.2007.00214.X

Duh, M. (2003). Family enterprises as an important factor of the economic development: The case of Slovenia. Journal of Enterprising Culture, 11(2), 111-130. https://doi.org/10.1142/S021849580300007X

Dunne, P., \& Hughes, A. (1994). Age, size and survival: UK companies in the late 1980s. Journal of Industrial Economics, 42(2), 115-140. https://doi.org/10.2307/2950485

Dyke, L. S, Fisher, E. M., \& Reuber, A. R. (1992). An inter-industry Examination of the Impact of owner experience on firm performance. Journal of Small Business Management, 30(4), 72-87.

Ferguson, P. R. (1993). Industrial economics: Issues and perspectives. Hong Kong: Macmillan.

Foley, P., \& Green, H. (1989). Small business success. London: Chapman.

Getz, D., Carlsen, J., \& Morrison, A. (2005). The family business in tourism and hospitality. Cambridge, M.A: CABI Publishing. https://doi.org/10.1079/9780851998084.0000

Grazzi, M., Pietrobelli, C., Szirmai, A. (2016). Determinants of Enterprise Performance in Latin America and the Caribbean: What Does the Micro-Evidence Tell Us? In Inter- American Development Bank, Grazzi M., Pietrobelli C. (Eds.), Firm Innovation and Productivity in Latin America and the Caribbean. Palgrave Macmillan, New York. https://doi.org/10.1057/978-1-349-58151-1_1

Haber, S., \& Reichel, A. (2005). Identifying measures of small ventures: The case of the tourism industry. Journal of Small Business Management, 43(3), 257-286. https://doi.org/10.1111/j.1540-627X.2005.00137.x

Haris, M. L., \& Gibson, S. G. (2006). Determining the common problems of early growth of small businesses in eastern and north Carolina. SAM Advanced Management Journal, 71(2), 39-45.

Islam, M. Z., \& Siengthai, S. (2010). Human resource management practices and firm performance improvement in Dhaka export processing zone. Research and Practice in Human Resource Management, 18(1), 60-77.

Keh, H. T., Nguyen, T. T. M., \& Ng, H. P. (2007). The effects of entrepreneurial orientation and marketing information on the performance of SMEs. Journal of Business Venturing, 22, 592-611. https://doi.org/10.1016/j.jbusvent.2006.05.003

Keskgn, H., Enturk, C., Sungur, O., \& Kgrg, H. M. (2010). The importance of SMEs in Developing Economies. 2nd International Symposium on Sustainable Development (pp. 183-192). Sarajevo.

Kotler, P. (1988). Marketing management: Analysis, planning, implementation and control (6th ed.). Englewood Cliffs, NJ: Prentice Hall, Inc.

Kristiansen, S., Furuholt, B., \& Wahid, F. (2003). Internet cafe entrepreneurs: Pioneers in information dissemination in Indonesia. The International Journal of Entrepreneurship and Innovation, 4(4), 251-263. https://doi.org/10.5367/000000003129574315

Kusuma, H. M., \& Mustiko, H. A. (2019). Determinants Small-Medium Enterprise Performance: Case of Batik Pekalongan in Indonesia. East African Scholars Journal of Economics, Business and Management, 2(9), 567574.

Laveren, E., Helleboogh, D., Molly, V., \& Limere, A. (2010). Family business succession and the impact of CEO experience on the growth of small family firms. International Journal of Entrepreneurship and Small Business, 11(3), 242-262. https://doi.org/10.1504/IJESB.2010.035817

Levitt, T. (1983). The marketing imagination. New York, NY: Free Press.

Lussier, R. N. (1995). A non-financial business success versus failure prediction model for young firms. Journal of Small Business Management, 33(1), 8-20.

Mabhungu, I., \& Breggie, V. D. (2017). A review of critical success factors which drives the performance of micro, small and medium enterprises. International Journal of Business and Management, 12(6). https://doi.org/10.5539/ijbm.v12n6p151

Maes, J., Sels, L., \& Roodhoof, F. (2005). Modelling the link between management practices and financial 
performance: Evidence from small construction companies. Small Business Economics, 25, 17-34. https://doi.org/10.1007/s11187-005-4255-y

Mahmoud, M. A. (2011). Market orientation and business performance among SMEs in Ghana. International Business Research, 4(1), 241-251. https://doi.org/10.5539/ibr.v4n1p241

McGahan, A. M., \& Porter, M. E. (1997). How much does industry matter, really? Strategic Management Journal, 18(Summer Special Issue): 15-30. https://doi.org/10.1002/(SICI)1097-0266(199707)18:1+<15::AIDSMJ916>3.0.CO;2-1

McMahon, R. G. P. (2001). Deriving an empirical development taxonomy for manufacturing SMEs using data from Australia's business longitudinal survey. Small Business Economics, 17(3), 197-212. https://doi.org/10.1023/A:1011885622783

Monk, R. (2000). Why small businesses fail? CMA Management, 74 (6), 12-13.

Moura, D. C., Madeira, M. J., \& Duarte, F. A. P. (2020). Cooperation in the Field of Innovation, Absorption Capacity, Public Financial Support and Determinants of the Innovative Performance of Enterprises. International Journal of Innovation Management. https://doi.org/10.1142/S1363919620500383

Msoka, E. M. (2013). Do entrepreneurship skills have an influence on the performance of women owned enterprises in Africa? Case of micro and small enterprises in Dar es Salaam, Tanzania. International Journal of Business, Humanities and Technology, 3(3).

Ndanusa, M., Manzuma-Ndaaba, Yoshifumi, H., \& Aminul, I. (2014). Challenges to growth in tourism industry of a developing country: The case of Nigeria. Asian Social Science, 10(19). https://doi.org/10.5539/ass.v10n19p282

Nganda, J. W., Wanyonyi, K. W., \& Kitili, E. M. (2014). Determinants of growth of small and medium enterprises in Kakamega central sub-county, Kenya. Journal of Business Administration and Management Sciences Research, 3(3), 22-31.

Nickels, W., McHugh, G. J., \& McHugh, S. (2005). Fundamentals of Business: Starting a Small Business. McGraw-Hill/Irwin: New York.

Nieman, G., Visser, T., \& Rene, V. W. (2008). Constraints facing tourism entrepreneurs in South Africa: A study in the Gauteng and Mpumalanga provinces. Development Southern Africa, 25(3) 283-296. https://doi.org/10.1080/03768350802212063

O'Gorman, C. (2001). The sustainability and growth in small and medium sized enterprises. International Journal of Entrepreneurial Behavior and Research, 7(2), 60-75. https://doi.org/10.1108/13552550110396095

Pena, I. (2002). Intellectual capital and business start-up success. Journal of Intellectual Capital, 3(2), 180-198. https://doi.org/10.1108/14691930210424761

Remi, A. J., Adegoke, A. A. I., \& Opoola, N. A. (2010). Impact of socio-economic factors on the performance of small-scale enterprises in Osun State. Nigeria International Business Research, 3(2). https://doi.org/10.5539/ibr.v3n2p92

Reuber, A. R., \& Fisher, E. (1999). Understanding the Consequences of Founder's Experience. Journal of Small Business Management, 37(2), 30-45.

Rogers, M. (2000). The role of diversification on firm performance. Melbourne Institute Working Paper No./00.

Roper, S. (1999). Modelling small business growth and profitability. Small Business Economics, 13, 235- 252. https://doi.org/10.1023/A:1008104624560

Rosli, M. M. (2011). Determinants of small and medium enterprises performance in the Malaysian auto- parts industry. African Journal of Business Management, 5(20), 8235-8241. https://doi.org/10.5897/AJBM11.889

Sarder, J. H., Ghosh, D., \& Rosa, P. (1997). The importance of support services to small enterprises in Bangladesh. Journal of Small Business Management, 35(2), 26-36.

Schiffer, M., \& Weder, B. (2001). Firm size and the business environment: Worldwide survey results. Discussions Paper, No. 43. Washington, D.C.: International Finance Corporation. https://doi.org/10.1596/0-8213-5003$\mathrm{X}$

Sinha, T. N. (1996). Human factors in entrepreneurship effectiveness. The Journal of Entrepreneurship, 5(1), 2339. https://doi.org/10.1177/097135579600500102 
Smallbone, D., Leig, R., \& North, D. (1995). The characteristics and strategies of high performance SMEs. International Journal of Entrepreneurial Behavior and Research, 1(3), 44. https://doi.org/10.1108/13552559510100657

Storey, D., Keasey, K., Watson, R., \& Wynarczyk, P. (1987). Performance of small firms: Profits, jobs, and failure. London: Croom Helm.

Stuart, R. W., \& Arbetti, P. A. (1990). Impact of entrepreneurial and management experience on early performance. Journal of Business Venturing, 5, 151-162. https://doi.org/10.1016/0883-9026(90)90029-S

Swierczek, F. W., \& Ha, T. T. (2003). Entrepreneurial orientation, uncertainty avoidance and firm performance: An analysis of Thai and Vietnamese SMEs. International Journal of Entrepreneurship and Innovation, 4(1), 46-58. https://doi.org/10.5367/000000003101299393

Timmons, J. A., \& Spinelli, S. (2003). New venture creation: Entrepreneurship for the 21st century (6th ed.). Boston: McGraw-Hill.

Tundui, C., \& Tundui, H. (2012). Survival, growth strategies and performance of women owned micro and small businesses in Tanzania. International Journal of Business and Management, 7(8). https://doi.org/10.5539/ijbm.v7n8p143

United Nations World Tourism Organization (UNWTO). (2011). A report on the opportunities and challenges which face women with respect to employment in tourism (UNWTO: Global Report on Women in Tourism 2010, Madrid).

Vinturella, J. B. (1998). The Entrepreneur's field Book. Upper Saddle River: Prentice-Hall.

Waseem, U. H.., Hisham, B. M., \& Hanita, B. K. S. (2020). Determinants of Micro-Enterprise Success through Microfinance Institutions: A Capital Mix and Previous Work Experience. International Journal of Business and Society, 21(2), 803-823. https://doi.org/10.33736/ijbs.3295.2020

Wengel, J., \& Rodriguez, E. (2006). SME export performance in Indonesia after the crisis. Small Business Economics, 26, 25-37. https://doi.org/10.1007/s11187-004-6491-y

Westhead, P. (1995). Survival and employment growth contrasts between types of owner- managed high technology firms. Entrepreneurship Theory and Practice, 20(1), 5-28. https://doi.org/10.1177/104225879502000101

Wijewardena, H., \& Tibbits, G. E. (1999). Factors contributing to the growth of small manufacturing firms: Data from Australia. Journal of Small Business Management, 37(2), 88-95.

Wynarczyk, P., \& Watson, R. (2005). Firm growth and supply chain partnership: An empirical analysis of U.K. SME subcontractors. Small Business Economics, 24, 39-51. https://doi.org/10.1007/s11187-005-3095-0

Yildiza, H. E., Murticb, A., Klofstenc, M., Zanderb, U., \& Richtnérb, A. (2021). Individual and contextual determinants of innovation performance: A Micro-Foundations Perspective. https://doi.org/10.1016/j.technovation.2020.102130

Zapalska, A. M., \& Brozik, D. (2014). Female entrepreneurial businesses in tourism and hospitality industry in Poland. Problems and Perspectives in Management, 12(2).

\section{Copyrights}

Copyright for this article is retained by the author(s), with first publication rights granted to the journal.

This is an open-access article distributed under the terms and conditions of the Creative Commons Attribution license (http://creativecommons.org/licenses/by/4.0/). 